\title{
Effect of Government Expenditures and Banking Loan Distribution on the Performance of Human Resource Development in Papua Province
}

\author{
Hendricus Lembang* \\ Department of Economics, Musamus University, Papua, Indonesia
}

\section{A R T I C L E I N F O \\ Article history: \\ Received 19 February 2019 \\ Received in revised form \\ 16 March 2019 \\ Accepted 15 April 2019 \\ Available online 26 May \\ 2019}

Keywords:

Capital spending, consumer

loan, investment, labor

absorption, Human

Development Index

\begin{abstract}
A B S T RA C T
The research aims to analyze government expenditure on capital spending and bank loan as well as to determine whether it has positive and significant effects on the Human Development Index (HDI) in Papua Province. The method is a quantitative study using a quantitive approach (deductive) to test the hypothesis and explain the causal relationship among panel variables (explanatory research). Data analysis techniques in the form of pooled data. Time series data were taken from 2005 to 2012 and the cross section data consisting of 19 regioncies and 1 city in Papua Province. The research results about the local government expenditure indicate that 10 the capital expenditure has positive and significant direct effect on an increase in private investment, educational level, employment recruitment and HDI, 2) the bank consumer loan distribution has positive and significant effect on the labor absorption, 3) the private investment has positive but not significant impact on educational level; it has positive and direct significant impact in the labor absorption, 4) the level of education has positive and direct significant impact on the employment recruitment and $\mathrm{HDI}, 5)$ labor absorption has positive and direct significant impact in the HDI.
\end{abstract}

\footnotetext{
* Corresponding author.

E-mail addresses: hendricuslembang@unmus.ac.id (Hendricus Lembang)
} 


\section{Introduction}

The paradigm shift in economic development occurred since the decade of the 1990s which was pioneered by Amartya Sen (2000). Economic development emphasizes the moral and ethical dimensions. The quality of development is people centered. So that, the quality of human resources is measured by the Human Development Index (HDI). Because economic growth is not merely the main indicator. It is not only meant to increase per capita income but also includes health, education, independence and freedom, (Neumayer, 2010).

This phenomenon has occurred in the Papua Province, on the one hand, economic growth has increased a positive trend. Even in 2009 had grown rapidly and reached to $22.22 \%$, (Central Statistics Agency, 2010). But the other hand, the achievement of HDI still places Papua Province as the last place in 33 provinces in Indonesia. An overview of the achievement development of the Papua Province HDI for 8 years by comparing the achievements of the national HDI as follows:

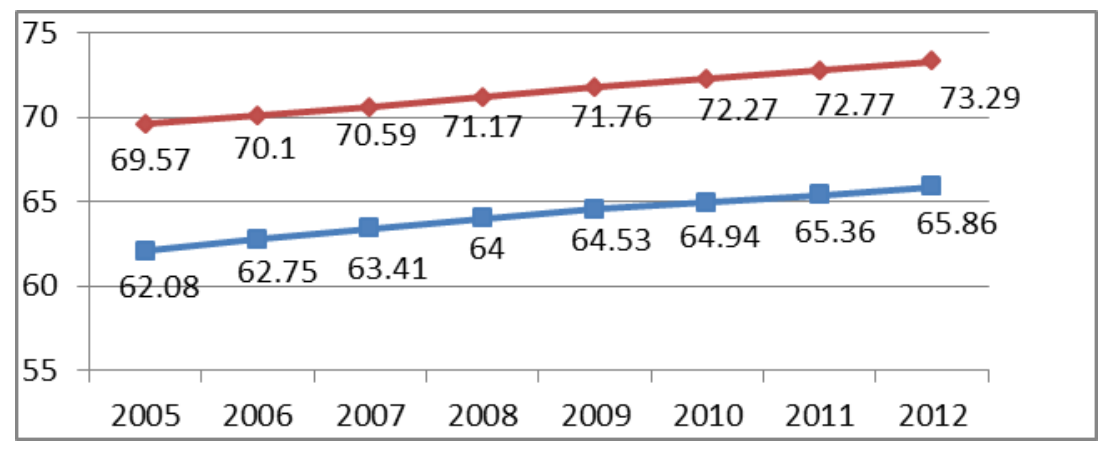

Figure 1. Papua Province HDI to the National HDI since 2005-2012

\section{Explanation:}

\begin{tabular}{l|l} 
& $:$ Graph for Papua Province HDI \\
& $:$ Graph for National HDI \\
Source & $:$ www.bps.go.id, Bappenas dan BPS
\end{tabular}

The improvement in the performance of human resources is Indonesia constitutional mandate, namely to educate the life of the nation and promote public welfare. Therefore, the aspect of well being is the substance of development. As the opinion of Frederick Harbinson (Todaro, 2011) that human resources are the basic capital of a nation's wealth. This is deal with the goal of development is to enable humans to be able and free to do what they want. (Neumayer, 2010). So that as an alternative to development is achieving fast growth, as well as distributing the benefits of growth equitable, (World Bank 2001b, Dagdeviren, 2001). Because welfare as bonum common (the general betterment of humanity) has a universal value that is always championed for by every government. (Smith B. Kevin et al. 2009).

Capital expenditure is an important factor for the development of quality human resources through the education, health and infrastructure sectors. In addition, it is a factor of private investors to open jobs so that they can reduce unemployment rates. Also the role of banking institutions to finance sectors in driving economic activities in the Papua Province.

\section{Literature Review}

Human resource development is an effort to increase one's capacity to expand one's opportunities in order to achieve a proper life. This effort is a human capability approach asncapability to function, according to Amartya Sen (Anand, S. and Sen, A. 2000; Todaro, 2011). Human resource development is very relevant to the opinions of Gustav Ranis and Stewart (2001) that human development is broadly in an effort to make people live longer, healthier and full life.

Increasing the human capability through improving education and health aspects, (Brata, 2005). So that they are able to utilize, develop and master science and technology to increase productivity, Mulyadi S. (2008). Human resource development is expressed in human capital concept by Theodore, W. Schultz (1961). Because the quality of human resources is a key factor in increasing high productivity and economic growth, (Barro, 1991). Then, Alfred Marshall asserted that "the most valuable capital of all capital is invested in human beings" (Becker, 1975). 
The combination of education and other physical investments that are very strong will contribute to productivity, (Psacharopoulos, 1989). For this reason, the government expenditure is needed, according to John Maynard Keynes (1936) that capital expenditure is a government financing post to finance public facilities in various economic activities. Expenditures through capital expenditure are part of the government's role in encouraging private investment as a highly recommended development strategy, (Hirschman, 1958). Furthermore, the opinion of Barro (1991) states that productive government expenditure will positively correlate with economic growth, while unproductive expenditure will negatively correlate.

Also according to Soepangat (1991; Badrudin, 2012), an increase in capital expenditure budget has an effect on increasing public welfare. The results of emperical research by Ranis state that government spending has a positive impact on improvements in education and health, especially for women, (Ramires and Stewart, 1998). However, it is different from the results of empirical research conducted by Hajibabaei, Hamidreza and Alimohammad Ahmadi (2014) that fewer government financing expenditures on Gross Domestic Product (GDP) will increase HDI, whereas if greater government spending will reduce HDI.

Likewise, banking loan is the driving force of economic growth functioning as a means to encourage the pace of the economy of a region. Similarly, consumer loan aims to buy consumer goods and services, (Stokes \& Artt, 1955; Rahman, 2009). So that this loan allows households to consume better, such as financing higher education. Because loan facilities will facilitate the consumption process as an effective means for households. This process has been called smoothing consumption. As consumer loan aims to improve living standards, (Suneja, 1994; Rahman, 2009). Consumers use loan as a source of financing to enter the middle class and improve the quality of their standard of living, (Longman, 2008). So that consumer loan provides many benefits as a multiplier effects. This consumer loan increases aggregate demand and economic growth, (Rajan \& Zingales, 2003; Longman, 2008). Dean Karlan and Jonathan Zinman (2007) state that an increase in loan distribution has a significant effect on welfare improvement.

Base on the background with the theories and the results of previous research, a framework is developed as shown in the figure below:

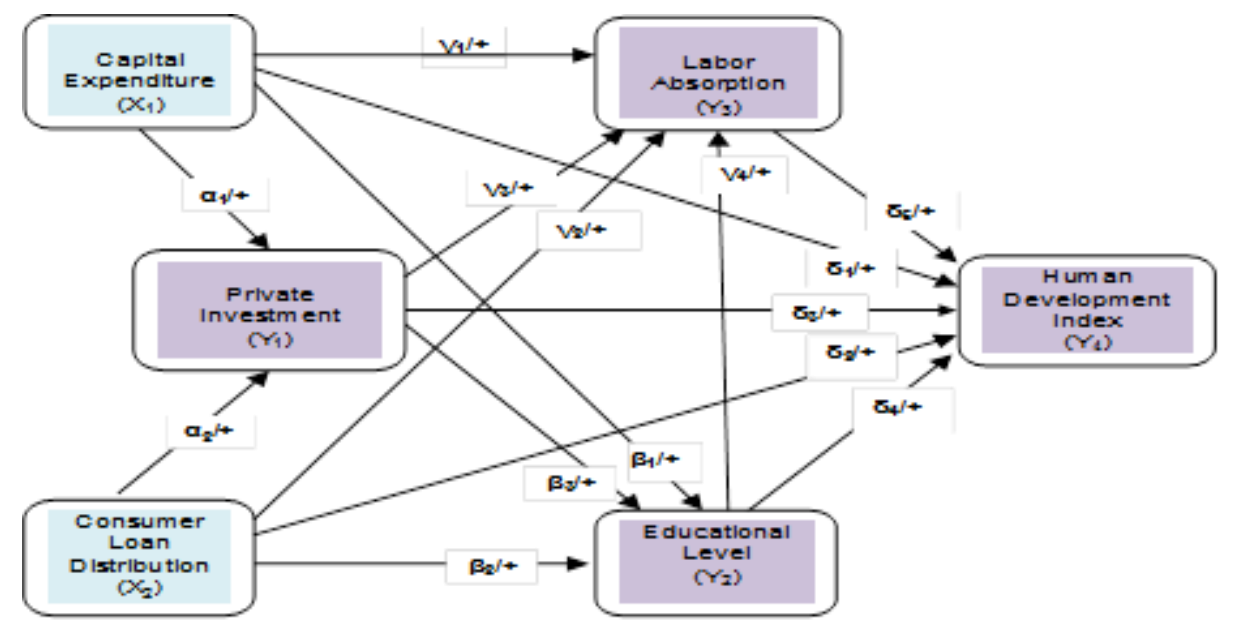

Figure 2.Research Framework

\section{Methods}

This type of research uses a quantitative (deductive) approach with an associative method which aims to test hypotheses and explain causality among variables. While the type of data used is pooled data which is a combination of time-series data and cross section with path analysis .Then the data panel regression model is used.

Based on the framework previously stated, functional equations can be formed in Structural Equation Model (SEM) as follows:

$$
\begin{array}{ll}
\mathrm{Y} 1= & \alpha 0+\alpha 1 \mathrm{X} 1+\alpha 2 \mathrm{X} 2+\mu 1 \quad(4.1) \\
\mathrm{Y} 2= & \beta 0+\beta 1 \mathrm{X} 1+\beta 2 \mathrm{X} 2+\beta 3 \mathrm{Y} 1+\mu 2 \quad(4.2) \\
\mathrm{Y}= & \gamma 0+\gamma 1 \mathrm{X} 1+\gamma 2 \mathrm{X} 2+\gamma 3 \mathrm{Y} 1+\gamma 4 \mathrm{Y} 2+\mu 3 \quad(4.3) \\
\mathrm{Y} 4= & \delta 0+\delta 1 \mathrm{X} 1+\delta 2 \mathrm{X} 2+\delta 3 \mathrm{Y} 1+\delta 4 \mathrm{Y} 2+\delta 5 \mathrm{Y} 3+\mu 4
\end{array}
$$




\section{Result and Discussion}

Effects of Capital Expenditures on Private Investment

Capital expenditure has a positive and significant effect on private investment with a path coefficient: 0.305 and p-value: 0,000. This indicates that the higher capital expenditure will encourage increased private investment in the Papua Province. Large capital expenditure in Papua Province is in line with the large size of block grant transfers from the central government in the form of General Allocation Funds and Special Allocation Funds. Therefore, Papua Province is the province that has the highest fiscal per capita in Indonesia. Whereas several regencies such as Mimika, Merauke, Jayapura Municipality and Jayapura Regence as developed regions in the Papua Province had an increase in revenue from Regional Original Revenues (PAD).

The development of capital expenditure for 8 years from 2005-2012 in Papua Province has made a positive growth which increased by an average of $8.81 \%$ every year. Capital expenditure to finance road infrastructure as a public facility can facilitate the flow of distribution and mobilization of both goods and people. Sea transportation infrastructure facilities will affect low-cost such as Frans Kaisepo port in Biak Numfor, Jayapura, Merauke, Amamapare in Mimika and Sentani, Jayapura Regency. Therefore there is economic efficiency by pressing variable costs.

In accordance with theory and opinion such as: Keynes (1936) that capital expenditure as a fiscal instrument to encourage aggregate demand can lead to multiplier effects and will contribute to increased investment. The development of investment value has made a positive trend in Papua Province which showed the volume of private investment value realization, namely domestic investment with an average growth of $8 \%$ per year and foreign investment average $11 \%$ per year during 2005-2012. Furthermore, the opinion of Tadaro (2011) says that public investment carried out by the government can encourage the investment climate and help facilitate production and trade. Then Musgrave and Hirschman (1958) state that spending through capital expenditure is part of the government's role in encouraging private investment. Likewise by Harrold-Domar (Sukirno, 2011) that government productive investment encourages economic growth and private investment in employment.

The results of this study are consistent with the results of empirical research conducted by several researchers such as: Nwosa, Philip Ifeakachukwu et al. (2013) which states that capital expenditure has a significant effect on foreign direct investment (FDI). Research by Onakoya, Adegbemi B. and Russell 0. Christopher Somoye (2013) states that public capital expenditure indirectly increases economic growth by encouraging private sector investment with the role of government facilities in the provision of public goods. The results of empirical research by Miar, Joko Mursinto (2014) state that the availability of infrastructure will help companies invest to reduce the average cost of infrastructure use.

\section{Effects of Capital Expenditures on Educational level}

Capital expenditure has a positive and significant effect on private investment with a path coefficient: 0.178 and p-value: 0.026 . This indicates that the higher capital expenditure will encourage an increase in the level of education in the Papua Province. Allocation of capital expenditure to finance regional development in order to provide public facilities and basic services in the education sector. Education funds have a very large portion that is regulated in the constitution, namely a minimum of twenty percent $(20 \%)$ from the national budget and regional budget to meet the needs and implementation of education.

Government expenditures such as: for the construction of school buildings, educational support facilities and infrastructure in a number of regencies / cities of the Papua Province. In 2012 there were 2,211 physical units for all levels of education. Most of the construction of school buildings from the elementary, middle and high school levels are in Merauke, Biak Numfor, Jayapura Regency and Jayapura Municipality, Nabire and Mappi Regency. There are 8 regencies / cities that have achieved high progress in educational level variables, namely Jayapura City, Merauke, Jayapura Regency, Mimika, Biak Numfor, Nabire, Boven Digoel and Mappi. The eight regencies have large capital expenditure budgets, especially for the construction of educational facilities and other supporting facilities.

The results of this study are in accordance with the human capability approach by Amartya Sen (Anand, S. and Sen, A. 2000; Todaro, 2011). Also Sariyono (2010) states that government expenditure per capita in education and health sectors and purchasing power has a significant and positive impact on increasing human development. Likewise, Munawwaroh (2013) states that the education and health budget has a significant effect on the level of education and the economy together has a significant effect on the quality of human resources among regencies / city in the Papua Province. 
Effects of Capital Expenditures on Labor Absorption

Capital expenditure has a positive and significant effect on employment with a path coefficient: 0.304 and p-value: 0,000 . This indicates that the higher capital expenditure will encourage increased employment in the Papua Province. The allocation of capital expenditure aims to increase private investment and labor absorption. Because the way to increase output is to add production input factors such as labor. Infrastructure development to expand new job opportunities (job creations) by promoting pro-jobs policies, which have the aim of increasing labor absorption. Labor absorption in Papua Province has had a positive trend of improvement. Regenc/City areas that are able to absorb the highest labor force in Papua Province, namely Merauke, Paniai, Jayawijaya, Nabire, Mimika, Pegunungan Bintang, Yahukimo, Tolikara and Jayapura Municipality.

In the agricultural sector, it is able to absorb workers which amounted to $1,133,982$ people or $77.85 \%$ of the total workforce in the Papua Province. Absorption of labor is like in Jayawijaya, Pegunungan Bintang, Yahukimo, Tolikara and Puncak Jaya Regency. The increasingly high absorption of labor in the Papua Province contributes positively to the decline in the open unemployment rate.

The results of this study are in accordance with Keynes Theory (1936), namely that the increase in government expenditure for employment. Then Harrold-Domar (Sukirno, 2011) that government spending encourages economic growth and private investment in employment. Likewise, the Labor Absorption Theory that to absorb labor, the policy adopted by the government was jobs creations. While the results of this study are consistent with the results of empirical research conducted by several researchers such as Halim (2008) that government investment in the public sector has a strong impact to absorb labors. Then Hendarmin (2012), Momuat, Rosita C. M. (2013), Kairupan, Siestri Pristina (2013) and Mubaroq, Muhammad Rizal, et al. (2013) that the capital expenditure budget allocation has a positive and significant effect on employment and reducing unemployment.

Effects of Capital Expenditures on Human Development Index

Capital expenditure has a positive and significant effect on the human development index with a path coefficient: 0.368 and p-value: 0.00 . This indicates that the higher capital expenditure will increase human development index in Papua Province. The increasing of the realization of the regional capital expenditure budget for financing the public sector reflects the seriousness of regencies/city in accelerating development.

There are 11 regencies / city that are able to reach the HDI in the upper middle category in Papua Province such as: Biak-Numfor, Puncak Jaya, Mimika, Yapen Islands, Keerom, Jayapura City, Merauke, Nabire, Sarmi, and Supiori. Increasingly the achievement of HDI is more in urban areas and regencies / city that have developed in lowlands on the coast. Because in general lowland regencies face little natural challenges. Whereas in the mountainous regions the welfare level is lower than in the lowlands. The main cause is the lack of access to infrastructure and natural conditions in rural areas, many of which are isolated from other areas and extensive terrain and natural conditions.

This is consistent with the theory of Keynes (1936) that fiscal policy is to finance infrastructure and public facilities, education and health for the public interest and public welfare. Then by Mahbub ul Haq with the Basic Needs Theory: (Fakih, 2001) that it is necessary to increase government expenditure in financing facilities directly related to basic needs for all levels of society. The results of this study are consistent with the results of empirical research conducted by several researchers such as: Wurarah, Ruly Novie, (2011) Munawwaroh (2013). Hendarmin (2012) Mirza, Denni Sulistio (2012) and Miar, Joko Mursinto (2014) that with the availability of infrastructure will have a positive effect on improving the quality of life by improving education and health services which will then improve the welfare of the community.

Effects of Banking Consumer Loan Distribution on Private Investment

The banking consumer loan allocation has a positive and significant effect on private investment with a path coefficient: 0.287 and p-value: 0,000 . This indicates that the higher capital expenditure will encourage increased private investment in the Papua Province. As consumer loan expansion from banking financial institutions in Papua is able to spur the economic growth. Therefore, the large volume of money and the velocity of money circulation is very useful in accelerating transactions in economic activities. The allocation of consumer loan is an integral part of the modern economy characterized by consumptive society. So that due to this consumptive pattern of society is able to stimulate various types of economic activities including encouraging the private sector to carry out investment activities in this area.

The Banking consumer loan allocation for 8 years from 2005 to 2012 had had positive trends. The regencies/city with the largest distribution of consumer loans in the high category are Mimika Regency, Jayapura City and Jayapura Regency. Then the upper middle category is Biak Numfor, Yapen Waropen and 
Merauke Regency. Therefore, an increase of consumption loan had a positive and significant effect on private investment in the Papua Province. This is in accordance with theories Malthus, (Jhingan, 2012) that high consumption will increase effective demand that drives economic growth. The results of this study are consistent with the results of empirical research conducted by several researchers such as: Rachman, et al. (2011) Nurkse (Sukirno, 2011) Utari et al. (2012) and Adewale, Aregbeshola R. (2014).

Effects of Banking Consumer Loan Allocation on Educational level

The banking consumer loan allocation has a positive and significant effect on educational level with a path coefficient: 0.209 and p-value: 0.009 . This indicates that the higher the allocation of consumer loan will promote level of education in the Papua Province. Expanding accessibility to the banking sector for the public will accelerate economic development. Because loan expansion will increase the volume of money that can facilitate economic activities. It provides economic progress in various aspects to fulfilling various community needs such as consumption of durable goods and services like quality education.

Consumption for financing education in more advanced regencies / city in Papua Province is a basic need for people to send their children pursuing higher levels and quality of education in outside the Papua Province and even in abroad. The Awareness of parents and their children interest to get quality education facilities, so it increased the demand of consumer loans to support education. So that the increase in the consumer loan allocation has a positive and significant effect on increasing the level of education in the Papua Province. This is related with the results of research by Pitt and Khandker (1998) that credit has a positive effect on improving the quality of human resources. Likewise by Soman, Dilip et al. (2002) stated that the growth in the amount of consumer loan cards was used to finance education.

\section{Effects of Banking Consumer Loan Allocation on Labor Absorption}

The Banking consumer loan allocation has a positive effect but not significant on labor absorption with path coefficient: 0.074 and p-value: 0.322 . This indicates an increase in loan allocation that does not push an increase in labor absorption in the Papua Province. Although the trend of increasing labor absorption during 8 years from 2005 to 2012, however, labor absorbed in the traditional and subsistence agriculture sector and civil servants due to the expansion of the new autonomous region.

This result is different from the hypothesis and theory which states that if the banking consumer loan allocation increases, it will increase labor absorption as Keynes (1936); (Jhingan, 2012) about the consumption theory which states that consumption will increase effective demand, thereby increasing labor absorption. Also the results of this study are not consistent with the results of empirical research conducted by several researchers such as by Rachman, et al. (2011) that consumer credit has an effect on economic growth (which will affect the absorption of labor and income).

\section{Effects of Banking Consumer Loan on Human Development Index}

The consumer loan allocation has a positive and significant effect on the human development index with a path coefficient: 0.176 and p-value: 0.010 . This indicates that the higher the allocation of consumer loan will promote an increase in the human development index in Papua Province. Expansion of consumer loan in the Papua Province encourages households to consume to fulfull various needs of their lives, such as vehicles, houses, household furniture, equipment for work activities and to meet the needs of better health and education services and also for family entertainment and recreation needs. The high use of consumer loan supports the improvement of a better and more prosperous standard of living which means increasing the human development index.

So that the increase in the consumer loan allocation has a positive effect to promote an increase in the human development index in Papua Province. This is in accordance with the theory and opinion such as: Pitt and Khandker (1998) that credit has a positive effect on improving the quality of human resources. Karlan, Dean and Yonathan Zinman (2007) consumer loans have significant benefits for borrowers in various economic segments and improve welfare. Likewise the results of research by Khandker, Shahidur R. and Rashidur R. Faruqee (2000), Rupelu (2008), Rachman, et al. (2011), Soman et al. (2002); (Sukirno, 2011). Soman, Dilip, and Amar Cheema (2002) and Longman, (2008) that consumer loan is a source of funding to enter the middle class and improve the quality of living standards, a means of social climbing.

\section{Effects of Private Investment on Educational Level}

Private investment has a positive but not significant effect on education with a path coefficient: 0.020 and p-value: 0.811 . This indicates an increase in private investment does not encourage increased education in the Papua Province. The development of education levels in several regencies/city increased in the Papua Province from 2005 to 2012 but the growth was not evenly distributed among regencies. 
There are still regiencies lagging behind ist development from other regions. The regencies in the highland areas, namely Keerom Regency, Pegunungan Bintang, Yahukimo and Tolikara.

The lagging education of this region is more in cuases by a high level of poverty living in those areas so that the economic weakness ability of families was an obstacle to obtain higher education. Other factors such as private investment do not recruit many highly educated workers in the Papua Province. Therefore, the quality of workers from outside Papua and even from abroad more productive so companies tend to directly bring highly qualified workers to fill the middle and upper levels.

This result is different from the hypothesis and the theory which states that if private investment increases so it will increase the level of education such as human capital investment by Shultz (1961), Chenery, Hollis B. (Tadaro, 2011) in the analysis of the pattern of development that the increasing of the industrial sector in the economy will increase in line with per capita income which is closely related to capital accumulation and increased human capital. Whereas Neumayer, Eric (2001) found that an increase in private investment has a positive effect on improving the quality of human resources.

\section{Effects of Private Investment on Labor Absorption}

Private investment has a positive and significant effect on employment with a path coefficient: 0.205 and p-value: 0.008 . This indicates that the higher private investment will encourage the increase of employment in the Papua Province. This is because more employment is absorbed by private companies, both foreign investment and domestic investment, which are absorbed more by workers to fill vacancies for plantation workers and field workers, and others that do not require many educational qualification requirements. The increase in private investment will have a positive effect to encourage labor absorption. This is in accordance with theories such as: Keynes (1936), that investment creates a multiplier effect that will be able to absorb a larger labor. Then by neoclassical flow (Sukirno, 2011; Jhingan, 2012), that labors will be absorbed along with the increase in capital invested. Likewise, HarrodDomar (Jhingan, 2012), that the rate of investment growth can solve structural unemployment. Furthermore, Arthur Lewis, (Sukirno, 2011; Jhingan, 2012) states that the role of capital formation for investments that can provide employment opportunities. The results of this study are also consistent with the results of empirical research conducted by several researchers such as: Situmorang, Elina (2007) stating that foreign investment is able to absorb labor. Similarly, Halim (2008), Suindyah, Sayekti, D. (2011) and Momongan, Junaidi E. (2013), that private investment have a significant effect on labor absorption.

\section{Effects of Private Investment on Human Development Index}

Private investment has a positive and significant effect on the human development index with a path coefficient : 0.143 and p-value : 0.048 . This indicates that the higher private investment will promote the increase in the human development index in Papua Province. The role of private investment in a number of regions, especially in areas such as Timika, Merauke, Jayapura Regency and Jayapura City are advanced regions. The existence of private companies is one of the driving forces of economic growth and human development index. This is in accordance with theories such as: Malthus (Jhingan, 2012) which states that continuous investment will enhance a steady and sustainable welfare. Then by Neumayer, Eric (2001) states that the increase in private investment has a positive effect in improving the quality of human resources. Likewise, Hendarmin (2012) found that private investment has a significant effect on welfare.

\section{Effefcts of Educational Level on Labor Absorption}

The educational level has a positive and significant effect on employment with a path coefficient : 0.179 and p-value : 0.014 . This indicates that the higher the level of education will encourage increased labor absorption in the Papua Province. The progress of educational level in Papua Province opens a wide opportunity to access various employment opportunities. Economic progress especially in developed regions such as Jayapura City, Jayapura Regency, Mimika and Merauke Regency, which have informal sectors and small industries that can be managed by young entrepreneurs who have higher levels of education.

This is in accordance with theory such as: Amartya Sen (Anand, S. and Sen, A. 2000; Todaro, 2011) with a human capability approach, capability to function. Human Capital Theory (Shultz, 1961) that the value of human capital is extremely determined by the intellectual workforce in increasing productivity. Furthermore, according to the Human Resources Development Theory, (Tjokroadjojo, 1980), that the growth of entrepreneurships, who have roles in development. They allow the growth of creating new jobs and self-employment. Likewise, Khadafih, Muhammad Fuad (2003) states that education level and wage variables have a positive effect on labor absorption. 
Effects of Educational Level on Human Development Index

The educational level has a positive and significant effect on the human development index with a path coefficient : 0.284 and p-value : 0,000. This indicates that the higher the educational level will promote an increase in the human development index in Papua Province. In human development capital there is a link between economic development and human resource development. Because people are the center and the ultimate goal of development which also means the subject and object in development.

Therefore, the expected development is to create a prosperous human in terms of economy, namely income and better education and health. This is in accordance with theories such as: Human Capital Theory (Shultz, 1961) that a person can promote his/her income through a higher level of education. The results of this study are consistent with the results of empirical research conducted by McMahon, Walter W. and Terry G. Geske (1982) and Munawwaroh (2013) that the educational level has a positive effect on the quality of human resources.

Effects of Labor Absorption on Human Development Index

Absorption of labor has a positive and significant effect on the human development index with path coefficients : 0.551 and p-value : 0.000 . This indicates that the higher the labor absorption will promote an increase in the human development index in Papua Province. This increase in employment in all regencies / city in Papua Province has caused opened unemployment rates to decline and to increase community income.

This is in accordance with theories such as: Rosenstein-Rodan, (Sukirno, 2011) that labor absorption will increase income. Likewise, Amartya Sen (Anand, S. and Sen, A. 2000; Todaro, 2011) with human capability approach that capability to function is the most important thing to determine someone poor status or not. The results of this study are consistent with the results of empirical research conducted by several researchers such as: Wurarah, Ruly Novie (2011) and also Hendarmin (2012), that labor absorption has a significant effect on welfare.

\section{Conclusion}

Based on the results of the research analysis and discussion, some conclusions can be drawn as follows: 1. Capital expenditures have a positive and significant direct effect on the increase in private investment, education level, employment and HDI in Papua Province as well as indirectly on labor absorption through private investment and educational level, as well as the HDI through private investment, education and labor absorption, 2. The banking consumer loan allocation has a positive and significant direct effect on private investment, educational level and HDI but is not directly significant for labor absorption but through the educational level and private investment, 3. Private investment has a positive but not significant effect on educational level. Private investment has a significant and positive direct effect on labor absorption and HDI and indirectly through labor absorption, 4 . The educational level has a positive and significant direct effect on employment and HDI and the educational level has an indirect and significant effect on HDI through labor absorption, and 5. Labor absorption has a positive and significant direct effect on HDI.

\section{Reference}

Adewale, Aregbeshola R., 2014. Financial Regulation, Loan Consumption and Economic Growth - An Analysis Of The National Loan Act In South Africa, The Journal of Applied Business Research March/April, Vol. 30, No 2.

Anand, S. and Sen, A. 2000. Human Development and Economic Sustainability, World Development, 20292049.

Badruddin, Rudi, 2012. Ekonomika Otonomi Daerah, UPP STIM YKPN, Yogyakarta.

Badan Pusat Statistik (BPS) , Papua Dalam Angka 2006 sampai dengan 2013

Barro, Robert J., May 1991. Economic Growth and The Asian Financial Crisis, Quarterly Journal of Economics, Vol. 106, No. 2. , pp. 407-443. 
Becker, S. Garry, 1975. Human Capital: A Theoretical and Empirical Analysis, the National Bureau of Economic Research, Volume ISBN: 0-226-04109-3.

Brata, Aloysis Gunandi, 2005. Investasi sektor Publik lokal, Pembangunan Manusida dan Kemiskinan, Lembaga Penelitian Universitas Atmajaya. Yogyakarta.

Dagdeviren, Hulya, Rolph Van der Hoeven, and John Weeks, 2001. Redistribution and Growth for Poverty Reduction, Working Paper series no. 118, July, ISBN No. 072860336 5, International Labour Organisation.

Fakih, Mansour, 2001. Runtuhnya Teori Pembangunan dan Globalisasi, Insist Press, Yogyakarta.

Hajibabaei, Hamidreza and Alimohammad Ahmadi, 2014. Government Size and Human Development: Quadratic Regression Approach, International Journal of Academic Research in Business and Social Sciences Vol. 4, No.4.

Halim, 2008. Analisis Investasi Sektor Publik Pemerintah (Belanja Modal) Daerah Yogyakarta, UPP STIM YKPN.

Hendarmin, 2012. Pengaruh Belanja Modal Pemerintah Daerah dan Investasi Swasta terhadap Pertumbuhan Ekonomi, Kesempatan Kerja dan Kesejahteraan Masyarakat di Kabupaten/Kota Provinsi Kalimantan Barat, Jurnal Ekonomi - Sosial, Oktober, Volume 8, Nomor 3.

Hirschman. A.O., 1958. The Strategy of Economic Development, New Haven, Yale University Press.

Jhingan, M.L., 2012. Ekonomi Pembangunan dan Perencanaan, Penerjemah D. Guritno. Cetakan ke-14, Raja Grafindo Persada, Jakarta.

Kairupan, Siestri Pristina, Desember, 2013. Produk Domestik Regional Bruto, Inflasi dan Belanja Daerah Pengaruhnya terhadap Kesempatan Kerja di Sulawesi Utara Tahun 2000-2012, Jurnal EMBA 2207 Vol.1 No.4.

Karlan, Dean dan Jonathan Zinman, 2007: Expanding Loan Access: Using Randomized Supply Decisions to Estimate the Impacts, National Science Foundation, the Princeton University Center for Migration, the Social Science Research Council Program in Applied Economics.

Keynes, J. M. 1936. The General Theory of Employment, Interest and Money. New York: Harcourt Brace.

Khadafi, Muhammad Fuad, 2013. Analisis Faktor yang Mempengaruhi Penyerapan Tenaga Kerja pada Industri Konveksi di Kota Malang, Jurnal Ilmiah, Fakultas Ekonomi dan Bisnis, Universitas Brawijaya Malang.

Longman, 2008. Different Paths to Mass Consumption: Consumer Loan in The United State and West Germany During the 1950s and 60s, Journal of Social History, January, Pennsylvania State University, USA.

McMahon, Walter W. dan Terry G. Geske, 1982. Financing Education: Overcoming Inefficiency and Inequality, University of Illinois Press, Urbana Illinois, USA.

Miar, Joko Mursinto, 2014. Influence of Government Expenses to Economic Growth and Manpower Absorption at Regencies/Cities in Central Kalimantan Province: periode 2003-2010, European Journal of Business and Management, Vol.6, No.8.

Mirza, Denni Sulistio, 2012. Pengaruh Kemiskinan, Pertumbuhan Ekonomi, dan Belanja Modal Terhadap Indeks Pembangunan Manusia di Jawa Tengah Tahun 2006-2009, Economics Development Analysis Journal, Universitas Negeri Semarang. 
Momongan, Junaidi E., September 2013. Investasi PMA dan PMDN Pengaruhnya terhadap Perkembangan PDRB dan Penyerapan Tenaga Kerja serta Penaggulangan Kemiskinan di Sulawesi Utara, Jurnal EMBA Vol.1 No.3, Hal. 530-539.

Momuat, Rosita C.M., 2013. Pengaruh Belanja Modal dan Tenaga Kerja Terhadap Pertumbuhan Ekonomi di Kota Manado, Jurnal Pembangunan dan Keuangan Daerah, Volume 10 No. 2.

Mubaroq, Muhammad Rizal, Sutyastie S. Remie dan Bagdja Muldjarijadi, 2013. Pengaruh Investasi Pemerintah, Tenaga Kerja dan Desentralisasi Fiskal terhadap Pertumbuhan Ekonomi Kabupaten di Indonesia 2007-2010, Jurusan Ilmu Ekonomi, Universitas Padjajaran, Bandung.

Mulyadi, 2008. Ekonomi Sumber Daya Manusia dalam Perspektif Pembangunan, Rajawali Pers, Jakarta.

Munawwaroh, 2013. Faktor-Faktor yang Mempengaruh Sumber Daya Manusia dan Perekonomian Kabupaten/Kota di Provinsi Jambi, Jurnal Kajian Ekonomi, Juli, Vol. II No. 03.

Neumayer, Eric, 2001. Analysis-The Human Development Index and Sustainability-A Constructive Proposal, Jurnal Ecological Economics, London Schools of Economics and Political Science.

Nwosa, Philip Ifeakachukwu, Adebiyi Oyeyemi Omodadepo dan Adedeji Adedayo Oluseun, 2013. An Analysis of the Relationship between Public Spending Components and Private investments in Nigeria, Journal of Finance \& Economics Volume 1, Issue 2, Published by Science and Education Centre of North America.

Onakoya, Adegbemi Babatunde dan Russell Olukayode Christopher Somoye, Februari 2013. The Impact of Public Capital Expenditure and Economic Growth in Nigeria, Global Journal of Economics and Finance Vol. 2 No.1.

Pitt, Mark M. and Shahidur R. Khandker. 1998. The Impact of Group-Based Loan programs on Poor Households in Bangladesh: Does the Gender of Participants Matter? Journal of Political Economy. Vol. 106, No. 5: 958-96.

Pollitt, C., Birchall, J., and Putnam, K. 1998. Decentralising Public Service Management. London: Macmillan.

Psacharopoulos, G. and Z. Tzannatos, 1989. Female Labor Force Participation: an International Perspective", The World Bank Research Observer, Vol. 4, No. 2, July.

Rachman, H. Zaini Fathor dan Agus Sriyanto, 2011. Analisis Kontribusi Investasi, Kredit Modal Kerja dan Kredit Konsumsi terhadap Pertumbuhan Ekonomi di Jawa Timur.

Rahman, Ataur, 2009. Consumer Loan as Lifestyle Activities Facilitators for Consumers of Bangladesh by, International Journal of Marketing Studies Vol 1 No. 2 Novermber.

Ranis, Gustav et al. 2001. Economic Growth and Human Development, World Development Vol. 28 No. 2, pp 197-2019.

Sariyono, 2010. Analisis Pengaruh Pengeluaran Pemerintah Bidang Pendidikan dan Bidang Kesehatan Serta Daya Beli Masyarakat Terhadap Peningkatan Indeks Pembangunan Manusia Di Kalimantan Selatan Tesis Pascasarjana Universitas Lambung Mangkurat .

Schultz, Theodore, W. 1961. Investment in Human Capital, American Economic Review, 36.

Soman, Dilip and Amar Cheema, 2002. The Effect of Loan on Spending Decisions: The Role of the Loan Limit and Credibility, Marketing Science Journal, Vol. 21, No. 1, Winter.

Smith, Kevin B. dan Christopher W. Larimer, 2009. The Public Policy, Theory Primer, West View Press, USA. 
Sukirno, Sadono, 2011. Ekonomi Pembangunan; Proses, Masalah dan Dasar Kebijakan Pembangunan, Prenada Media Group, Jakarta.

Suindyah, Sayekti, D., Desember 2011. Pengaruh Investasi, Tenaga Kerja dan Pengeluaran Pemerintah terhadap Pertumbuhan Ekonomi di Propinsi Jawa Timur, Jurnal Ekuitas, Vol. 15 No. 4.

Tjokroadjojo, Bintoro dan Mustopadidjaya A. R., 1980, Teori Strategi Pembangunan Nasional, Gunung Agung, Jakarta.

Todaro, Michael P. dan Stephen C. Smith, 2011. Pembangunan Ekonomi, Jilid 1, Penerbit Erlangga, Jakarta.

Wurarah, Ruly Novie, 2011. Pengaruh Belanja Modal terhadap Pertumbuhan Ekonomi dan Penyerapan Tenaga Kerja serta Kesejahteraan Masyarakat di Provinsi Papua Barat, Disertasi Universitas Airlangga, Surabaya. 